\title{
A new species of Decimiana Uvarov (Insecta, Mantodea, Acanthopidae) from Brazil, with remarks on the distribution of Decimiana bolivari (Chopard)
}

\author{
Eliomar da Cruz Menezes ${ }^{1, \dagger}$, Freddy Bravo $\stackrel{\text {, }}{ }$ \\ I Laboratório de Sistemática de Insetos, LABIO, Departamento de Ciências Biológicas, Universidade Estadual \\ de Feira de Santana, Av. Transnordestina, S/N, Novo Horizonte, 44.036-900, Feira de Santana, Bahia, Brazil \\ † urn:lsid:zoobank.org:author:D54F148C-2FB5-49E7-9F8F-76C4EF69912E \\ † urn:lsid:zoobank.org:author:4999C681-C5D4-4F46-AC46-73D87C33D17A \\ Corresponding author: Eliomar da Cruz Menezes (mazinhomenezes@hotmail.com)
}

Academic editor: Sam Heads | Received 7 June 2012 | Accepted 26 October 2012 | Published 2 November 2012 urn:lsid:zoobank.org:pub:70F61D62-70F9-4E46-9640-0814D76B295D

Citation: Menezes EC, Bravo F (2012) A new species of Decimiana Uvarov (Insecta, Mantodea, Acanthopidae) from Brazil, with remarks on the distribution of Decimiana bolivari (Chopard). ZooKeys 236: 55-64. doi: 10.3897/ zookeys.236.3477

\begin{abstract}
Decimiana Uvarov is a Neotropical genus of Mantodea with five South American species, three of them known from Brazil: Decimiana tessellata (Charpentier); Decimiana clavata Ippolito \& Lombardo; and Decimiana bolivari (Chopard). A fourth species from Brazil is described and new records of Decimiana bolivari (Chopard) from Brazil are presented and its distribution discussed.
\end{abstract}

\section{Keywords}

Dictyoptera, Neotropical region, Bahia, Chapada Diamantina, Caatinga

\section{Introduction}

The Decimiana name was proposed by Uvarov (1940) to replace the genus name Decimia, designated by Stål (1877), due to homonymy with a genus of Lepidoptera (Travassos 1945). This genus was created in monotype to Acanthops tessellata Charpentier, 1841 (Travassos 1945; Lombardo 2000). 
Decimiana tessellata (Charpentier, 1841), was designated based on Seba's illustration (1765: 75, Fig. 11) (Travassos 1945). Illustration which historically were also attributed the representation of species Acanthops falcataria (Goeze, 1778) [=Mantis falcataria Goeze] and Mantis bisubulata Goeze, 1778 considered a junior synonym of D. tessellata despite the name priority (Travassos 1945; Lombardo 2000). Lombardo (2000) to analyze the same Seba's illustration concludes that represent $D$. tessellata.

Lombardo (2000) in his revision of the genus includes Decimiana bolivari (Chopard, 1916) [=Acanthops bolivari Chopard], Decimiana rehni (Chopard, 1913) [=Plesiacanthops rehni Chopard], transferred from other genera, and described Decimiana hebardi Lombardo. Later Ippolito and Lombardo (2004) described Decimiana clavata, a species know only from the holotype male. In his revision Lombardo (2000) affirms describe the first time the males of D. bolivari, species that had been described based on females. However, in a study of morphologic stamp, Heitzmann-Fontenelle (1964) describes and figure the male and female of Acanthops erosula Stål, 1877, which corresponds in reality to $D$. bolivari (Lombardo and Ippolito 2004).

The genus Decimiana has Neotropical distribution and their five species are recorded only in South America (Lombardo 2000, Ippolito and Lombardo 2004). Of which three species occurs in Brazil: Decimiana bolivari (Chopard) from Paraguay and Brazil (Bahia State, in the northeastern region, and Mato Grosso do Sul State, in the central-western region); Decimiana clavata Ippolito \& Lombardo from Brazil (with no mention of a specific locality); Decimiana hebardi Lombardo from Bolivia; Decimiana rehni (Chopard) from Argentina and Paraguay; and Decimiana tessellata (Charpentier) from Paraguay and Brazil (Mato Grosso and Goiás states, central-western region) (Terra 1995, Lombardo 2000, Ippolito and Lombardo 2004).

In this contribution, we described a new species of Decimiana from Bahia State in the northeastern region of Brazil. Additionaly, we provide and discuss new distributional records for $D$. bolivari from Brazil.

\section{Methods}

All of the specimens were collected using a light trap. To study the male genitalia, the abdomens of the specimens were detached behind the eighth segment and treated according to the protocols of Cumming (1992). The male genitalia were stored in plastic microvials containing glycerin and pinned with their corresponding specimen. The terminology for external morphological follows Terra (1995), whereas genitalia terminology is based on Cerdá (1993). The studied specimens were deposited in the Coleção Entomológica Professor Johann Becker do Museu de Zoologia da Universidade Estadual de Feira de Santana (MZUEFS), Feira de Santana, Bahia State, Brazil; the Museu de Zoologia da Universidade Federal da Bahia (UFBA), Salvador, Bahia State, Brazil and Centro de Pequisa Gonçalo Moniz da Fundação Oswaldo Cruz (FIOCRUZ), Salvador, Bahia State, Brazil. 


\section{Taxonomy}

The new species have the following diagnostics characteristics of the genus: presence of compound eyes with conical tubercle; costal margin of the mesothoracic wings with slight concavity; posterior wings with black stripes on cross veins; mid and hind legs without lobes, and anterior process of the ventral lamina developed (sensu Lombardo 2000).

\section{Decimiana elliptica sp. $\mathbf{n}$.}

urn:lsid:zoobank.org:act:7F0879A2-1852-4ACE-8518-F7B4475EF1F2

http://species-id.net/wiki/Decimiana_elliptica

Figures 1-3

Type material. Holotype male: BRASIL, Bahia, Palmeiras, Posto do Pai Inácio, $12^{\circ} 27.00^{\prime \prime S}, 41^{\circ} 28.00 " \mathrm{~W}$, ca. $900 \mathrm{~m}$ a.s.l. 09.XII.2007, Bravo, F., Zacca, T., Silva-Neto, A., Resende, J., \& Almeida, C. col., (MZUEFS \#42169). Paratype male: BRASIL, Bahia, Mucugê, Chapada Diamantina, Parque Municipal de Mucugê, 30.I.2011, light trap, Mahlmann, T. \& Hipólito cols. (UFBA).

Etymology. The name makes reference to the shape the anterior lobe of the left dorsal phallomere.

Diagnosis. Compound eyes conical with apical tubercle; mesothoracid wings opaque, brown, with costal margin slightly concave; posterior wings with black bands between the crossveins; anterior process of the left dorsal phallomere with distal sclerotized lobe elliptical.

Description male. Body stout, brown (Fig. 1), length 38.64-42.68 mm from head to subgenital plate.

Head (Fig. 2A). Triangular, 1.67 times as wide as width of supracoxal dilatation. Antennae moniliform, brown, 1.07 times the length of the pronotum. Ocelli developed, elliptical. Vertex: rectilinear, below the imaginary line connecting top of compound eyes (not including the apical tubercle). Frontal shield transversal, 0.53 times wider than high.

Thorax. Pronotum, 0.27 times as long as length of body, 4.87 times longer than its smallest width, lateral margins smooth, surface with scattered small tubercles, distributed along sides of the medial carina (Fig. 2B). Prozona: anterior margin rounded, lateral margins slightly convergent. Metazona 2.05 times as long as length of prozona, with two basal flattened tubercles.

Fore legs. Coxae: stout, reaching base of proesternum, 0.75 as long as length of pronotum; anterior, posterior, and external margins with minute dispersed spines; posterior external face with small scattered tubercules, inner face with some circular ocher spots. Fore femora: stout, triangular, 0.94 times as long as the length of the pronotum; external face with small tubercules; 16 inner spines, except the spines of the genicular lobes; femoral spines of the three series black at tip. Fore tibiae: 0.55 as long 


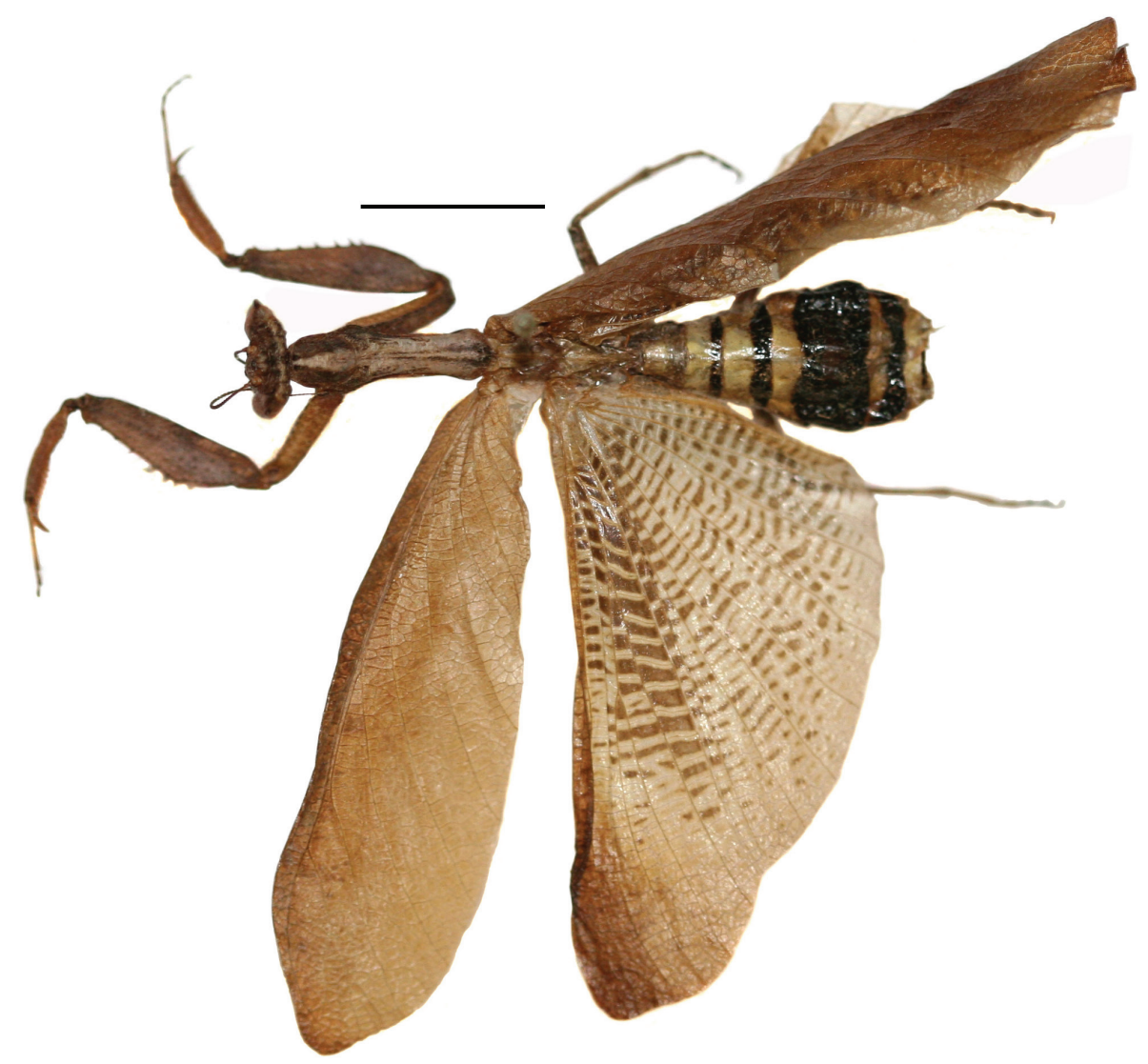

Figure I. Decimiana elliptica sp. n., holotype, dorsal habitus. Scale bar $=10.00 \mathrm{~mm}$.

as length of pronotum (not including the tibial claw); 20-21 external spines in left leg and 18-19 in right leg; 16 inner spines; external and inner tibial spines black at tips.

Mesothoracic wings: 3.29 times as long as length of pronotum, surpassing the abdomen at rest, and same length as posterior wings. Surface opaque and brown. Costal margin slightly concave and with small apical lobe (Fig. 2C). Venation brown. Venules of the costal area anastomosed.

Mid legs: pubescent; femora and tibiae 0.58 times as long as length of pronotum; first tarsomere shorter than length of all remaining tarsomeres.

Metathoracis wings: 3.03 times as long as length of pronotum, surface semi-hyaline; venation brown.

Hind legs: pubescent; femur 0.70 times as long as length of pronotum; tibiae 0.73 times as long as length of pronotum; first tarsomere shorter than length of all remaining tarsomeres.

Abdomen. Cylindrical; second to fourth and sixth tergite with distal black stripe, fifth tergite black; fourth and sixth tergite with rounded lateral lobe. Supranal plate: 1.47 times wider than length, distal margin bidentate (Fig. 2D). Cerci: bristly, cylin- 


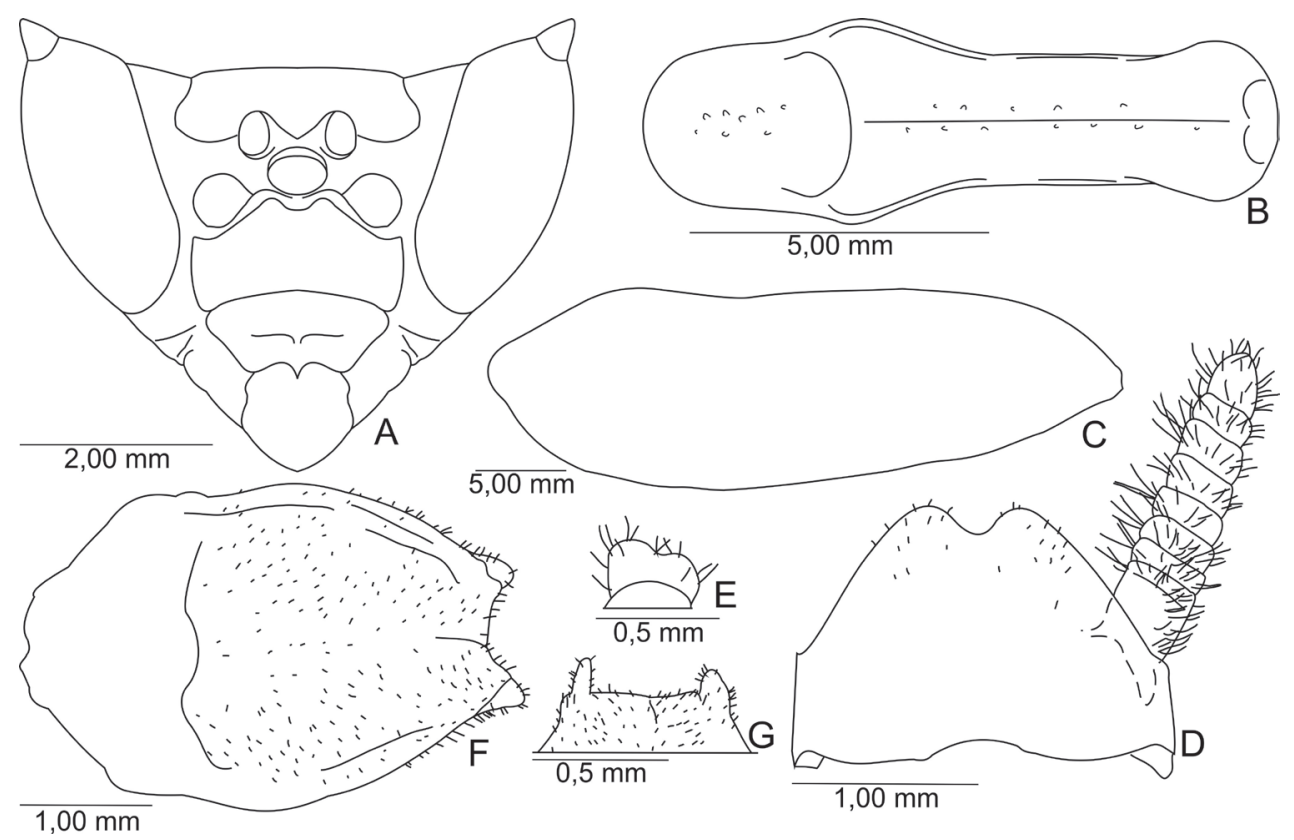

Figure 2. A-D, F holotype; E, G paratype. A Head, frontal view B Pronotum, dorsal view C Shape of the left mesothoracic wings, dorsal view D Supranal plate and cercus, dorsal view E Last cercomerum F Subgenital plate, ventral view G Distal margin of the subgenital plate, ventral view.

drical, eight cercomeri, last cercomerum cylindrical or bilobed (Fig. 2E) and slightly flattened. Subgenital plate: pubescent, oval (Fig. 2F). Styles: bristly, separated, small or more developed (Fig. 2G).

Phallic complex. Right dorsal phallomere. Dorsal lamina triangular (Fig. 3A). Mid arm: developed, arched. Anterior apodeme long and narrow. Ventral plate sclerotized, well developed, trapezoidal, projected, with transverse grooves. Ventral process sclerotized, curved and well developed, as long as of ventral plate, forming acute angle backward (Fig. 3B).

Left dorsal phallomere. Dorsal lamina: ample, basal region narrow; right basal region membranous (Fig. 3C). Ventral lamina long and wide forming an anterior process, with distal sclerotized elliptical dentate lobe, connected to a lateral row of teeth which can be undeveloped (Fig. 3D). Apical process flattened, folded toward base of phallomere. Phalloid apophysis membranous, forming a relatively large and pilose lobe. Membranous lobe wide (approx. half the width of dorsal lamina), rounded and with long hair.

Ventral phallomere (Figs 3E, 3F). Elongated (aprrox. 1,84 times longer than wide). Tip of the right margin with well-sclerotized and acute anterior process, its surface covered with denticles. Distal process sclerotized, upward, with small denticles on anterior margin.

Female unknown.

Measurements (mm). Holotype: body length 38.64, pronotum length 10.6, mesothoracic wings 34.93 , metathoracic wings 32.2 , fore coxae 8.0 , fore femura 9.97 , fore tibiae 5.91, mid femura 6.15, mid tibiae 6.15, hind femura 7.4, hind tibiae 7.82. 

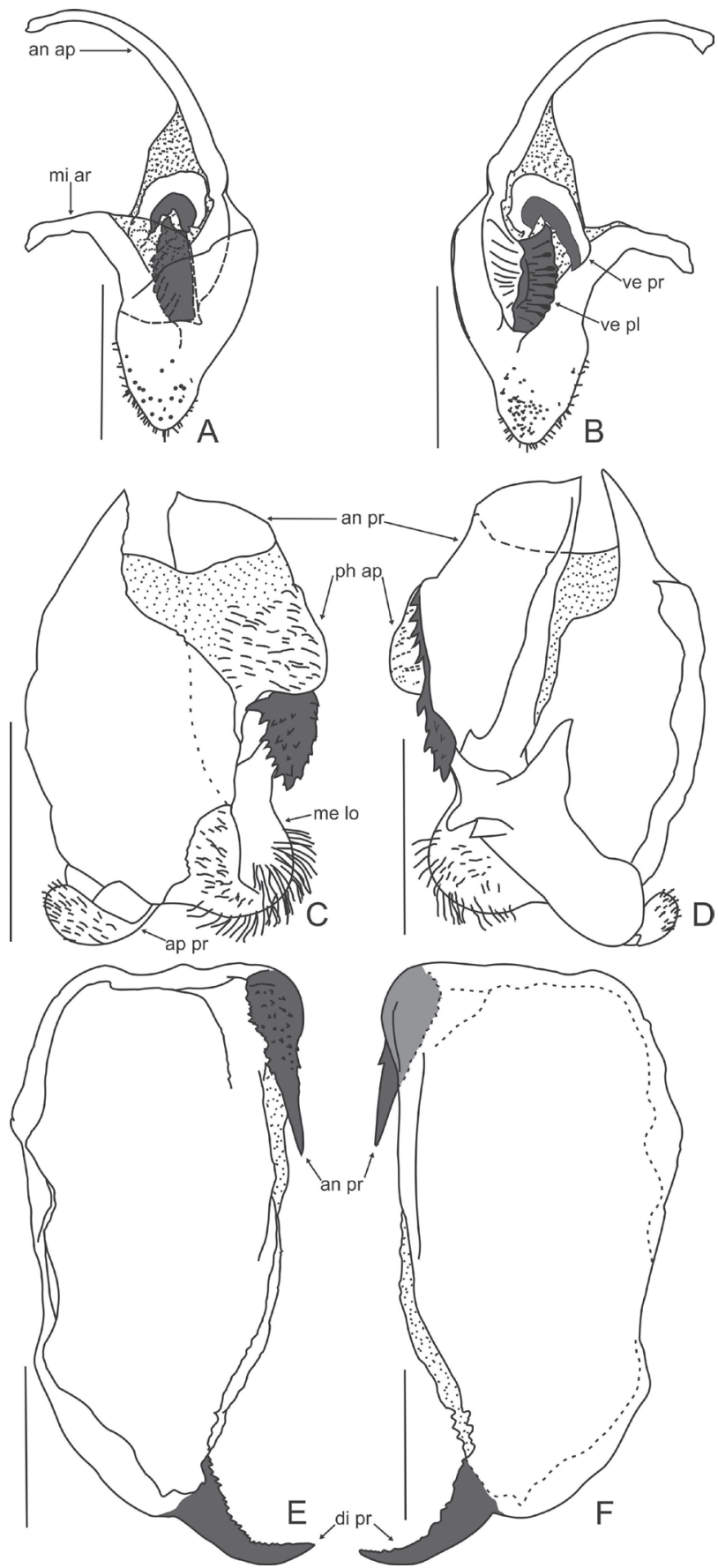

Figure 3. Decimiana elliptica sp. n., holotype. A Right dorsal phallomere, dorsal view B Right dorsal phallomere, ventral view C Left dorsal phallomere, dorsal view D Left dorsal phallomere, ventral view E Ventral phallomere, dorsal view $\mathbf{F}$ Ventral phallomere, ventral view. Abbreviations: an ap $=$ anterior apodeme, $\mathbf{a n} \mathbf{p r}=$ anterior process, $\mathbf{d i} \mathbf{p r}=$ distal process, $\mathbf{m e ~} \mathbf{l o}=$ membranous lobe, $\mathbf{m i}$ ar $=$ mid arm, $\mathbf{p h}$ $\mathbf{a p}=$ phalloid apophysis, $\mathbf{v e} \mathbf{p l}=$ ventral plate, $\mathbf{v e} \mathbf{p r}=$ ventral process. Scale bar $=1.00 \mathrm{~mm}$. 

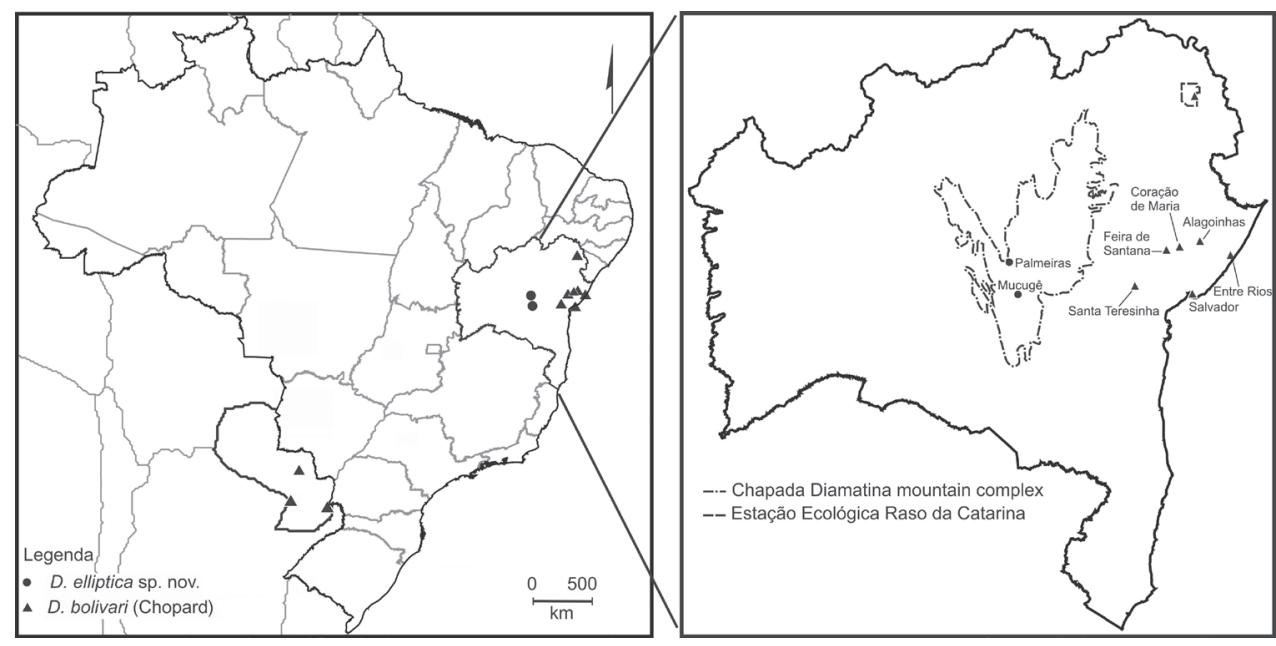

Figure 4. Geographical records of Decimiana elliptica sp. n. and Decimiana bolivari (Chopard).

Paratype: body length 42.68, pronotum length 11.71 , mesothoracic wings 38.58 , metathoracic wings 35.57 , fore coxae 8.83 , fore femura 11.01 , fore tibiae 6.52 , mid femura 6.79, mid tibiae 6.79, hind femura 8.17, hind tibiae 8.63.

Type localities. The type specimens were collected in two localities in the Chapada Diamantina Mountain Range in Bahia State, northeastern Brazil: Parque Municipal de Mucugê (municipality of Mucugê) and near a mountain known as Morro do Pai Inácio (municipality of Palmeiras) (Fig. 4). The Chapada Diamantina represents the northern portion of the Espinhaço Range (Rocha et al. 2005) and according Velloso et al. (2002) it is considered an eco-region of the Caatinga (dryland) Biome, with a rainy season generally from November to April. The vegetation of the Chapada Diamantina is a mosaic of "caatinga", "cerrado de altitude", "campos rupestres", and semideciduous and deciduous forests.

\section{Discussion}

Regarding the right dorsal phallomere is only possible to compare with D. bolivari, accurately illustrated by Heitzmann-Fontenelle (1964) Fig. 5. Fact that we attest by confrontation with the material examined of $D$. bolivari. Since the literature uses the lack of description and illustration of this phallomere in the other species of genus.

The ventral lamina in the right dorsal phallomere in D. elliptica sp. n. is grooved while in $D$. bolivari is covered by spines. The ventral process in the new species is more curved in the base and more elongated than in D. bolivari.

The anterior process of the left dorsal phallomere is developed and anteroposteriorly perpendicular to phallomere in D. elliptica sp. n., D. bolivari, D. herbardi, D. rehni and D. tessellata (Figs 3C, 3D; Heitzmann-Fontenelle 1964: Fig. 6; Lombardo 2000: 
Figs 27-29,31), and . differs from $D$. clavata because the anterior process is less developed and oblique (Ippolito and Lombardo 2004: Figs 4, 5). In the new species the anterior process of the left dorsal phallomere has truncated shape, while $D$. bolivari, $D$. herbardi, D. rehni it is sack-shaped and in D. tesselata has an expanded apex.

On the surface of the anterior process of the left dorsal phallomere are absent in D. elliptica sp. $n$. the minute spines that are present in D. bolivari and D. herbardi, as well as, are absent in the new species the teeths present in D. rehni and the large apical teeths observed in D. tesselata.

The anterior process of the left dorsal phallomere in D. elliptica sp. n. and D. clavata has a distal esclerotized lobe, which it is absent in D. bolivari, D. herbardi, D. rehni and D. tessellata. However, this sclerotized lobe is elliptical in D. elliptica sp. n. and bludgeon-shaped in D. clavata.

The membranous lobe of the left dorsal phallomere the new species is relatively greater and more rounded than the other species, except for $D$. clavata which it is most similar.

D. elliptica sp. $\mathrm{n}$. has the ventral phallomere more elongated than the other species (Fig. 3E). The anterior process of the ventral phallomere elongated as in D. bolivari (Heitzmann-Fontenelle 1964: Fig. 2), D. rehni (Lombardo 2000: Fig. 25) and D. herbardi (Lombardo 2000: Fig. 26). The distal process of the ventral phallomere of new species resembles that of $D$. bolivari in the form, curved upwards. However differs the distal process of $D$. tessellata who is backwards, and the distal process of D. rehni which is more curved and short.

\section{Notes on the distribution of Decimiana bolivari (Chopard, 1916)}

Material examined: BRASIL, Bahia: Alagoinhas, 24.X.1993, D. H. Smith, col., male (UFBA). Coração de Maria, Distrito de Retiro, 07.XI.2010, Franklin Machado col., male (MZUEFS \#53183); ib., female (MZUEFS \#53180). Entre Rios, 07.V.2008, Silva-Neto, A. col., male (MZUEFS \#39218). Feira de Santana, 16.XII.1999, Márcia col., male (MZUEFS \#13268); ib., 14.V.2001, Ivan Castro col., male (MZUEFS \#13269); ib., 08.XI.2003, F. Bravo col., male (MZUEFS \#13285). Salvador, 23.IV.1985, D. H. Smith, col., male (UFBA); ib., 2.X.1952, Afonso Braga, col., 1 male (FIOCRUZ); ib., 13.V.1962, Ivo Silva col., male (FIOCRUZ). Santa Teresinha, Serra da Jibóia, ca. 800 m a.s.l., VIII.2004, Raimunda col., male (MZUEFS \#28123); ib., 29.III.2009, male (MZUEFS \#46032). Estação Ecológica Raso da Catarina, 14.VI.1981, D. H. Smith, col., male (UFBA).

In his review of Decimiana, Lombardo (2000) stated that D. bolivari was only present in Paraguay (known records from Asunción, "central Paraguay", Horqueta, Puerto Bertoni, Puerto San Pablo y Sapucay, sensu Lombardo 2000); however, he did not comment on the Brazilian records made by Terra (1995), who reported (without mentioning specific localities) that $D$. bolivari occurs in the Brazilian states of Mato Grosso do Sul and Bahia. He also no mention Heitzmann-Fontenelle (1964) that record D. bolivari in state of Mato Grosso do Sul, Serra do Urucum. Because of the lack of refe- 
rences to specific material, it was impossible to locate the specimens studied by Terra (1995) and thus these records cannot be confirmed. Ehrmann (2002) and Agudelo et al. (2007) followed the distributions of D. bolivari presented by Lombardo (2000).

However, we confirm herein the occurrence of $D$. bolivari in Bahia state for the following localities: Alagoinhas, Coração de Maria, Entre Rios, Feira de Santana, Salvador, Santa Teresinha (Serra da Jibóia) and Estação Ecológica Raso da Catarina (Fig. 4). These confirmed records considerably expand the distribution of D. bolivari, to the Brazilian northeast.

It is important to mention that the specimens of $D$. bolivari from Bahia were collected in various ecosystems encompassing a wide array of different climates and plant formation. This species was recorded from localities in ombrofilous Atlantic Rain Forest with a moist climate (Entre Rios and Salvador), in transitional ecosystems between Caatinga (dryland) and Atlantic Rain forests (Alagoinhas, Coração de Maria, Feira de Santana, Santa Teresinha) with semi-arid to moist climates, and in semideciduous forest/caatinga and semi-arid caatinga/deciduous forest (Raso da Catarina Ecological Station) (Velloso et al. 2002, IBGE 2011, SEI 2011). D. bolivari was also collected at sea level (e.g. Entre Rios and Salvador) and up to approximately 800 (Santa Teresinha, Serra da Jibóia) (IBGE 2011, SEI 2011, collection data). and Pantanal region, domained. In Mato Grosso do Sul state (Serra do Urucum), D. bolivari is recorded in the Pantanal ecosystem, where occurs the plant formations: steppic savanna/seasonal forest; savanna/steppic savanna and steppic savanna grass-woody (IBGE 2004).

$D$. bolivari seems to be a species well adapted to different biotic, environmental, and altitudinal conditions, further collections will provide a additional insights on the actual extent of its distribution.

\section{Acknowledgments}

The authors would like to thank the Programa de Pesquisa em Biodiversidade do Semiárido (PPBio/ Semi-árido) for financing the research and collections. To Thiago Mahlmann by the specimen collection and sending to the first author. To the entomological collection of the Universidade Federal da Bahia and Centro de Pesquisa Gonçalo Moniz da Fundação Oswaldo Cruz for the loan specimens to MZUEFS.

\section{References}

Agudelo AA, Lombardo F, Jantsch LJ (2007) Checklist of the Neotropical mantids (Insecta, Dictyoptera, Mantodea). Biota Colombiana 8(2): 105-158.

Cerdá F (1993) Valor taxonómico del complejo fálico en Mántidos Neotropicales (Dictyoptera: Mantodea). Boletín de Entomología Venezolana 8(1): 33-52.

Cumming J (1992) Lactic acid as an agent for macerating Diptera specimens. Fly Times 8: 7. Ehrmann R (2002) Gottesanbeterinnen der Welt. Münster: Natur und Tier Verlag, 519 pp. 
IBGE (2004) Instituto Brasileiro de Geografia e Estatística. Mapa de vegetação ftp://ftp.ibge. gov.br/Cartas_e_Mapas/Mapas_Murais/vegetacao_pdf.zip

IBGE (2011) Instituto Brasileiro de Geografia e Estatística http://www.ibge.gov.br/cidadesat/

Heitzmann-Fontenelle TJ (1964) Estudos morfológicos de Acanthops erosula Stål, 1877 (Mantodea, Acanthopidae). Papéis Avulsos de Zoologia, 16: 229-241.

Ippolito S, Lombardo F (2004) Decimiana clavata, a new species from Brazil (Mantidae). Memorie della Società Entomologica Italiana 82(2): 373-378.

Lombardo F (2000) A review of the genus Decimiana Uvarov, 1940 (Insecta:Mantodea), with description of a new species. Proceedings of the Academy of Natural Sciences of Philadelphia 150: 159-171.

Lombardo F, Ippolito S (2004) Revision of the species of Acanthops Serville, 1831 (Mantodea, Mantidae, Acanthopinae) with comments on their Phylogeny. Annals of the Entomological Society of America 97:1076-1102. doi: 10.1603/0013-8746(2004)097[1076:ROT$\mathrm{SOA}] 2.0 . \mathrm{CO} ; 2$

Rocha WJSF, Chaves JM, Rocha CC, Funch L, Juncá FA (2005) Avaliação Ecológica Rápida da Chapada Diamantina. In. Juncá FA, Funch L, Rocha W (Eds) Biodiversidade e Conservação da Chapada Diamantina. Ministério do Meio Ambiente, Brasília, 29-45.

SEI (2011) Superintendência de Estudos Econômicos e Sociais da Bahia http://www.sei. ba.gov.br

Terra PS (1995) Revisão sistemática dos gêneros de louva-a-deus da região Neotropical (Mantodea). Revista Brasileira de Entomologia 39(1): 13-94.

Travassos LF (1945) Sobre a família Acanthopidae Burmeister, 1838, emend. (Mantodea). Arquivos de Zoologia do Estado de Sáo Paulo 4:157-232.

Velloso AL, Sampaio EVSB, Pareyn FGC (2002) Ecorregiōes Propostas para o Bioma Caatinga. Associação Plantas do Nordeste, Instituto de Conservação Ambiental The Nature Conservancy do Brasil, Recife, 76 pp. 